\title{
Political Science and Conservation Biology: a Dialog of the Deaf
}

\author{
ARUN AGRAWAL* AND ELINOR OSTROM $†$ \\ *University of Michigan, 440 Church Street, SNRE, Ann Arbor, MI 48109, U.S.A., email arunagra@umich.edu \\ †Indiana University, Workshop in Political Theory and Policy Analysis, 513 North Park, Bloomington, IN 47408, U.S.A.
}

Political scientists have largely ignored conservation biology and its central concern, biodiversity. Consider two indicators and an anecdote. The indicators concern publication trends and faculty hiring in political science. In the past 20 years, the top five political science journals, as measured by their impact factor scores, have published one article focusing on biodiversity conservation (out of more than 2000 published papers). And in the top five political science departments in the United States (arguably, Harvard, Princeton, Stanford, Yale, and Chicago), not a single faculty member considers biodiversity conservation to be among his or her research interests. The anecdote concerns reflections on the discipline by 12 recent past presidents of the American Political Science Association. In remarking on the blind spots, research accomplishments, and needed directions for the discipline, biodiversity was entirely absent; indeed, even the environment was.

These facts should rightly generate pessimism about the past and future of conversations between political science and conservation biology. Political scientists and their discipline value work on biodiversity at best only to a limited extent. To the extent that political scientists consider conservation biology and biodiversity, they must do so by working against the disciplinary incentive structures that reward research and teaching.

The reasons political scientists neglect conservation biology and biodiversity may lie even deeper than incentives related to publication and hiring. They may have more to do with what political scientists view as the most important issues and the appropriate scale at which to study them. Electoral systems and practices, democracy, political institutions, international regimes, public opinion, state-society relations, conflict, war, violence, race and ethnicity, policy making, strategic behavior, and policy outcomes are properly the province of their discipline according to most political scientists. Few see biodiversity as central to the concerns of political science. Furthermore, political scientists tend to value research at the nation-state level far more than that conducted on subnational units of analysis. Much of the research in conservation biology, in contrast, takes place at far finer scales than those denoted by national boundaries. Vigorous cross-disciplinary conversations may also be missing because of important differences in corresponding world views. For most political scientists, strategic behavior is central to human interactions. For most conservation biologists, one might argue, the imperative to protect the environment, specifically biodiversity, is beyond strategic calculation.

Despite a bleak history of interactions, the future of conversations between political science and conservation biology can be brighter. Some political scientists have written, at times passionately, about the importance of conserving biodiversity (Sanderson 2002; Sanderson \& Redford 2003; Thomas 2003; Moran \& Ostrom 2005). The writings of others have had a significant impact on the practical programs and policies related to conservation and biodiversity. The work on resistance by Scott (1985) has influenced the extent to which local people are viewed as having an important role in the success of conservation policies. Ostrom's (1990) work on the commons has helped shape the thinking of a generation of those interested in institutional arrangements to protect resources and biodiversity. And Putnam's (1993) study of social capital has similarly influenced many who believe that strong civil-society organizations are necessary to create pressures favorable to positive policies for biodiversity and the environment more broadly.

Certainly, the world's ecosystems face grave challenges and these challenges cannot be met without a deeper analysis and understanding of politics and institutions. As

Paper submitted November 15, 2005; revised manuscript accepted February 16, 2006. 
political scientists, and somewhat parochial ones to boot, we believe political science can contribute significantly to the study and practice of conserving the planet's biological diversity.

Some political scientists may think the most important contributions from their discipline are in the domain of international regulatory regimes that govern biodiversity and analysis of biodiversity policies in specific countries and across nations. We agree that the problem of biodiversity conservation often requires actions by national governments and international agencies, and insights from regime theory, state-society interactions, and the large literature on coalition formation, governance, and policy formation are valuable sources to understand how and when political actors create conditions favorable for conservation.

But ultimately biodiversity conservation requires concerted effort at multiple levels. Local actors are critical in the protection of ecological resources, both in the short and long run. The same is true of subnational units of governance. Without acute political analyses that take incentives and actions of multiple actors at different scales into account, there is no effective policy making or governance related to biodiversity and, consequently, no protecting biodiversity.

For example, protected areas are often viewed as a critical component in the race to preserve biodiversity. National government proclamations that create protected areas are no guarantee of conservation. Without the involvement of local actors in the definition of boundaries, a clear understanding of which resources can be harvested and by whom, and monitoring of biodiversity conservation processes, protected areas are likely to be little more than paper parks. Worse, as just a region demarcated on a map, a protected area may make things worse by generating disrespect for established boundaries among local peoples and accelerated harvesting pressures because of local beliefs that an important resource has been alienated. Without substantial local efforts in favor of conservation, formal protection efforts for biodiversity are always likely to remain inadequate (Hayes \& Ostrom 2005). The point is general. Rather than emphasize a particular institutional strategy, the diversity of requirements for adaptive governance that leads to conservation and long-term sustainability needs to be identified (NRC 2002; Dietz et al. 2003). Ecologists have long recognized the dangers of monocultures when it comes to agriculture or the management of other biological resources. As Evans (2004) poignantly observes, we are still relying on monocultures when it comes to recommending the best institutions to achieve the conservation of biological resources.

Conservation biologists and political scientists have common cause in recognizing that political organization is itself a multiscale phenomenon similar to ecological systems. A small but growing number of useful studies are beginning to confront the challenge that the number of elements involved in sociopolitical as well as ecological systems is extremely large (Ostrom 2005). Furthermore, most of the elements are themselves parts of larger systems and can be broken down into subparts of nearly decomposable systems. The eminent political scientist Herbert Simon (2000:753) described these as nearly decomposable systems "arranged in levels, the elements at each level being subdivisions of the elements at the level above." Arthur Koestler (1973) provides us with a similar concept about partially separable systems that are nested in a hierarchical set of systems through the term bolon.

In both ecological and governance systems, then, many units of analysis are very small and relatively independent of other units at the same level of analysis but parts of larger subsystems. Thus, instead of thinking only of national governments or local systems when thinking about ways of conserving biodiversity, it is necessary to examine the scale at which governance processes intersect with the dynamics of ecological systems. We need to identify how different units of governance are organized and the scales at which such units set boundaries, devise appropriate rules, and monitor conformity with rules for longterm sustainability. Strengthening governance systems at relevant scales is perhaps the most important challenge of the next century for biodiversity conservation.

\section{Literature Cited}

Dietz, T., E. Ostrom, and P. Stern. 2003. The struggle to govern the commons. Science 302:1907-1912.

Evans, P. 2004. Development as institutional change: the pitfalls of monocropping and the potentials of deliberation. Studies in Comparative International Development 39:30-52.

Hayes, T. M., and E. Ostrom. 2005. Conserving the world's forests: are protected areas the only way? Indiana Law Review 38:595-617.

Koestler, A. 1973. The tree and the candle. Pages 287-314 in W. Gray and N. D. Rizzo, editors. Unity through diversity. Part I. Gordon and Breach Science Publishers, New York.

NRC (National Research Council). 2002. The drama of the commons. In E. Ostrom, T. Dietz, N. Dolšak, P. Stern, S. Stonich, and E. Weber, editors. Committee on the Human Dimensions of Global Change. National Academy Press, Washington, D.C.

Moran, E., and E. Ostrom, editors. 2005. Seeing the forest and the trees: human-environment interactions in forest ecosystems. Massachusetts Institute of Technology Press, Cambridge, Massachusetts.

Ostrom, E. 1990. Governing the commons: the evolution of institutions for collective action. Cambridge University Press, Cambridge, United Kingdom.

Ostrom, E. 2005. Understanding institutional diversity. Princeton University Press, Princeton, New Jersey.

Putnam, R. 1993. Making democracy work. Cambridge University Press, Cambridge, United Kingdom

Sanderson, S. 2002. The future of conservation. Foreign Affairs 81:162173.

Sanderson, S., and K. Redford. 2003. Contested relationships between biodiversity conservation and poverty alleviation. Oryx 37:389-390.

Scott, J. C. 1985. Weapons of the weak: everyday forms of peasant re sistance. Yale University Press, New Haven, Connecticut.

Simon, H. 2000. Public administration in today's world of organizations and markets. Political Science and Politics 33:749-756.

Thomas, C. 2003. Bureaucratic landscapes: interagency cooperation and the preservation of biodiversity. Massachusetts Institute of Technology Press, Cambridge, Massachusetts. 